Discussion Paper No. 12-032

\title{
How do Banks Screen Innovative Firms? Evidence from Start-up Panel Data
}

Martin Brown, Hans Degryse, Daniel Höwer, and María Fabiana Penas

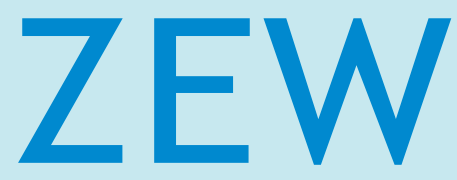

Zentrum für Europäische Wirtschaftsforschung $\mathrm{GmbH}$

Centre for European Economic Research 
Discussion Paper No. 12-032

\title{
How do Banks Screen Innovative Firms? Evidence from Start-up Panel Data
}

\author{
Martin Brown, Hans Degryse, Daniel Höwer, \\ and María Fabiana Penas
}

Download this ZEW Discussion Paper from our ftp server:

http://ftp.zew.de/pub/zew-docs/dp/dp12032.pdf

Die Discussion Papers dienen einer möglichst schnellen Verbreitung von neueren Forschungsarbeiten des ZEW. Die Beiträge liegen in alleiniger Verantwortung der Autoren und stellen nicht notwendigerweise die Meinung des ZEW dar.

Discussion Papers are intended to make results of ZEW research promptly available to other economists in order to encourage discussion and suggestions for revisions. The authors are solely responsible for the contents which do not necessarily represent the opinion of the ZEW. 


\section{Non-technical summary}

In this working paper we analyse bank screening with regard to the use of hard and soft information. We are interested in differences in the effect of an external credit rating on the use of bank finance, the share of bank to total finance and bank difficulties between newly founded firms in High-Tech vs. Low-Tech industries. We analyse the effect of different rating classes, as well as the availability of a rating. Further we examine whether the effect of bank characteristics differ between High-Tech and Low-Tech firms. In particular, we look at the effects of bank size as a proxy for the bank's hierarchal structure and the bank's expertise and specialization in the firms industry.

We employ the KfW/ZEW start-up panel dataset covering 9,715 firms established in the years 2005-2009. The panel tracks firms over the period 2007-2009 and we can make use of up to three consecutive firm observations. Each firm is assigned with its credit rating provided by Creditreform. Each firm is linked with the characteristics of its main bank.

Our results also suggest that banks rely less on external rating information in their decision making for High-Tech firms. The availability of a credit rating hampers access to bank finance only when the rating is bad. Firms without rating or with a fair or good rating have similar access to bank finance suggesting that banks only employ negative signals from credit ratings in their decision making. We find an interesting difference between High-Tech and Low-Tech firms as our results seem to indicate that a bad rating is less harmful in terms of bank finance for firms in the High-Tech sector than in the Low-Tech sector.

The size of a firm's main bank also determines whether start-ups face difficulties in obtaining bank finance. Our results suggest that firms that have their main relation with a larger bank use less bank finance and report more difficulties in getting credit. By contrast, a larger expertise of the bank in the firm's industry is not associated with fewer difficulties to get bank loans. Bank expertise affects the bank share but there is no evidence on difficulties. 


\section{Nicht-technische Zusammenfassung}

In diesem Arbeitspapier untersuchen wir die Verwendung von harten und weichen Informationen in der Kreditentscheidung von Banken an junge Unternehmen. Das Forschungsinteresse liegt darin, ob sich der Effekt eines negativen Ratings in der Bankfinanzierung von Unternehmen in Hightech von Lowtech-Sektoren unterscheidet. Die Effekte werden in Bezug auf die Nutzung von Bankmitteln, den Anteil der Bankmittel am gesamten Finanzierungsvolumen und die Schwierigkeiten bei einer Bankfinanzierung untersucht. Des Weiteren wird analysiert, ob sich der Einfluss von Bankcharakteristika auf die Nutzung von Bankmitteln zwischen Hightech und Lowtech Unternehmen unterscheidet. Hier betrachten wir die Bankgröße als Maß für die Hierarchie der Bank und die Expertise der Bank in der Industrie des Unternehmens.

Wir verwenden das KfW/ZEW Gründungspanel und beobachten die Finanzierungsstruktur für 9.715 Unternehmen, die zwischen 2005 und 2009 gegründet wurden. Jedem Unternehmen wird das entsprechende Krediturteil, das von Creditreform zur Verfügung gestellt wird, zugewiesen. Zudem wird das Unternehmen mit den Charakteristika seiner Hausbank verknüpft.

Die Ergebnisse zeigen, dass Banken externe Ratings weniger stark im Screeningprozess von Hightech Unternehmen einsetzen. Der Kreditzugang wird lediglich durch ein schlechtes Rating beeinflusst, wenn es sich um ein Lowtech Unternehmen handelt. Auch der Anteil der Bankfinanzierung wird lediglich bei Lowtech Unternehmen negativ durch die erstmalige Verfügbarkeit eines negativen Ratings beeinflusst. Schwierigkeiten mit einer Bankfinanzierung nehmen mit der Größe der Hausbank zu. Die Schwierigkeiten nehmen dabei nicht durch eine Expertise der Bank in der Industrie des Unternehmens ab. Allerdings zeigt sich, dass Unternehmen deren Hausbank eine hohe Expertise haben einen höheren Anteil an Bankfinanzierung nutzen. 


\title{
How do Banks Screen Innovative Firms? Evidence from Start-up Panel Data*
}

by

\author{
Martin Brown \\ University of St. Gallen \\ martin.brown@unisg.ch \\ Hans Degryse \\ KU Leuven, EBC - Tilburg University and CEPR \\ H.Degryse@uvt.nl \\ Daniel Höwer \\ ZEW \\ hoewer@zew.de \\ María Fabiana Penas \\ Tilburg University - CentER, TILEC and EBC \\ M.Penas@uvt.nl
}

May 2012

\begin{abstract}
Start-up firms often face difficulties in raising external funds. Employing a unique panel dataset covering 9,715 start-up firms over the period 2007-2009, we find that high-tech startups are less likely to use bank finance and face more difficulties in raising bank finance than low-tech start-ups. We find that external credit scores do affect the availability of credit for start-up firms, but that banks rely less on external rating information in their decision making for high-tech start-ups than low-tech start-ups. Start-ups that have their main relation with a small bank use more bank finance and report less difficulties in getting credit. By contrast, a greater expertise of the bank in the firm's industry is not associated with fewer difficulties to get bank loans. There are no differences between high-tech and low-tech start-ups regarding the impact of bank size.
\end{abstract}

Keywords: Innovation, Start-up, Credit information sharing, Soft information

JEL Codes: G2, G18, O16, P34

* The authors are grateful to SEEK/ZEW for financial support and providing access to the dataset. We thank seminar participants from Tel-Aviv University for helpful comments. 


\section{Introduction}

Newly created firms and in particular high-tech start-ups are the engines of growth in many countries. However, start-up firms - low-tech and high-tech - often face difficulties in raising the required funds to implement their ideas. Banks are argued to be less willing to provide funds to start-ups as these firms lack collateral and are more opaque (see however Robb and Robinson (2012) showing that banks are more important in financing start-ups than previously thought). Asymmetric information regarding creditworthiness and a lack of tangible capital may arguably lead to stronger credit constraints for high-tech start-ups as opposed to low-tech start-ups.

Banks apply a variety of techniques to overcome information asymmetries between themselves and their borrowers. First, they engage in relationship banking, producing information on their clients through (multiple) interaction with them (Boot 2000). Second, they acquire and process external information on borrowers provided by credit bureaus (Jappelli and Pagano, 2006). ${ }^{1}$ Third, they mitigate adverse selection and moral hazard through contract design, i.e. by differentiating the maturity, size or collateral conditions of loans. $^{2}$

We employ a novel dataset - the German KfW/ZEW start-up panel - to study three questions. First, we examine whether high-tech start-ups face more difficulties in accessing bank credit than low-tech start-ups. Second, we examine how banks' use of "hard” credit bureau information to screen new borrowers affects lending to start-ups, and whether the role of credit bureau information in the screening process differs between low-tech and high-tech start-ups. Third, we examine how lending to start-up firms is related to the use of "soft" information within the bank and internal expertise of the bank. Again we examine whether the role of bank-internal information and expertise differs for high-tech start-ups as opposed to low-tech start-ups.

The KfW/ZEW start-up panel provides us with a rich picture of the financing decisions and financing problems of start-ups during their first years of existence. The panel provides us with a nationally representative sample of start-ups stemming from a bank-based

\footnotetext{
${ }^{1}$ Examples of information sharing institutions in Germany are Schufa (credit bureau focussed on bank-borrower and utility-client payments) and Creditreform (credit reference agency focussed on firm-firm payment behavior).

${ }^{2}$ Adverse selection can be overcome by offering a range of self-selecting loan contracts to borrowers, which may differ e.g. in collateral requirements (Bester 1985), size (Freixas and Laffont 1990), or maturity (Flannery 1986). Moral hazard due to non-observable actions of borrowers or costly state-verification can also be mitigated through collateral requirements (Bester 1985), or repeated short-term lending (Bolton and Sharfstein 1990).
} 
economy (Germany) where banks are important in providing external finance to firms. We employ data from the 2008, 2009 and 2010 waves of the panel which cover financing information for 9,715 firms over the period 2007-2009. Of these firms 4,972 are observed once, 2,902 are observed twice and 2,309 are observed in all three waves leading us with 15,000 firm-year observations.

Our main findings can be summarized as follows. First, high-tech start-up firms are less likely to use bank finance and face more difficulties in raising bank finance than lowtech firms. This suggests that firms from industries that exhibit a greater research and development intensity employ less bank finance. Second, information provided by an external credit bureau does affect access to bank finance for start-ups. Firms with a fair or good rating have similar access to bank finance as firms without rating, while firms with a bad rating are more likely to have difficulties getting bank credit. We find though that banks rely less on external rating information in their decision making for high-tech start-ups compared to low-tech start-ups. Third, start-ups that have their main relation with a small bank use more bank finance and report less difficulties in getting credit. This finding suggests that banks which rely more on "soft information” generated through relationship banking are more likely to lend to start-ups. By contrast, a larger expertise of the bank in the firm's industry is not associated with fewer difficulties to get bank loans. We find no differences, in the impact of bank size on high-tech as opposed to low-tech start-ups.

Our results have important policy implications. Recent bank capital regulations introduce a more prominent role for external credit ratings about firms. Policy makers might be concerned that financiers of innovative firms start to rely too much on credit ratings provided by credit bureaus. We find that this concern is unwarranted as banks seem to rely less on external ratings in their loan decision making for high-tech firms than for low-tech firms. In particular, a bad rating obtained by a high-tech firm is less harmful for its bank funding than a negative rating for a low-tech firm. The bigger reliance on credit bureaus therefore does not seem to require any specific policy intervention regarding high-tech firms. Our results do further suggest that the trend towards more concentration in the banking sector may have detrimental impacts on credit availability for start-up firms. We find that start-ups which use larger banks indeed face more difficulties in obtaining bank finance. However, this result applies for all types of start-ups - low-tech and high-tech - suggesting that policy intervention for innovative firms is unwarranted.

Our paper contributes to three current strands of literature in the field of entrepreneurship and financial intermediation: (i) the financing of start-ups, (ii) the impact of 
credit information sharing on credit assessment and credit availability, and (iii) the relation between bank organization and lending technology.

Young and innovative firms differ in several dimensions from established firms, and are especially prone to financial constraints. In addition to a high degree of uncertainty associated with the output of innovative investment, the entrepreneur or inventor is better informed than investors about the nature of the project and the likelihood of success (Hall 2009). This implies that the lender-firm relationship is more exposed to adverse selection and moral hazard (Stiglitz and Weiss 1981) for start-ups with innovative investments than for those with traditional investment or established firms. Firms can mitigate financing problems by offering collateral (Bester 1985, Harhoff and Körting 1998) or building up reputation developed through repeated interactions (Boot 2000). Innovative firms may have difficulties providing collateral since most $\mathrm{R} \& \mathrm{D}$ expenditures consists of worker wages and salaries and the assets created are intangible and idiosyncratic and therefore have a low salvage value (Hall 2009). Lerner (1995) and Gompers and Lerner (1996) stress that, compared to venture capitalists, banks face more difficulties in monitoring firms with few tangible assets. Recent evidence on start-ups financial structure shows that banks are the main supplier of external funds to small and young businesses both in Europe and in the US. In the specific case of high tech firms, outside equity such as venture capital, plays in general a more important role than debt (Bozkaya and Pottelsberghe 2008). Due to lack of data, one key aspect missing in the recent empirical literature is the relation between start-ups credit availability and the characteristics of banks. We find that start-ups financed by larger banks face more financial difficulties whereas start-ups dealing with banks with a greater expertise in an industry do not seem to relax credit constraints.

Second, our paper contributes to the growing empirical literature on the role of information sharing for the functioning of credit markets. Theory suggests that sharing of information among creditors can reduce adverse selection (Pagano and Jappelli 1993) and entrepreneurial moral hazard (Padilla and Pagano 1997) in bank-borrower relationships. Several recent empirical studies employing micro datasets, cross-country datasets, and experiments have demonstrated that credit information sharing is beneficial to credit market performance. Credit scoring models based on credit agency data suggests that the use of credit reports allows lenders to more accurately predict loan defaults (Kallberg and Udell, 2003). Also, credit information sharing improves firm's repayment performance (Doblas- 
Madrid and Minetti 2009). ${ }^{3}$ There is scarce evidence to date on how credit information sharing affects credit availability for start-up firms. This is, however, an important issue. If banks rely strongly on credit history information for their credit assessment, this may have a negative impact on those prospective borrowers which do not have a (bank-) credit history. Start-up firms typically lack a history of bank-credit. However, the entrepreneur may have a personal credit history and after an initial phase the firm may have a history of paying utility and supplier bills. This information may be particularly valuable for a bank's credit assessment when it deals with innovative start-ups for which information asymmetries are particularly strong. Using data from the Kauffman survey in the US, Cerqueiro and Penas (2010) and Robb and Robinson (2010) find that information on payment behavior (or the absence of it) does affect access to credit for start-up firms. We contribute to this literature by comparing the impact of credit bureau information on access to credit for high-tech as opposed to low-tech firms. Our results suggest that this role may indeed be weaker for innovative firms.

Third, there is a large theoretical and empirical literature showing that banks with different organizational structure use different types of information in their credit assessment and rely on different contractual terms to mitigate information asymmetries. Stein (2002) argues that in large, hierarchical banks the incentives of a loan officer to acquire "soft" information about his clients are muted, as this information cannot be verifiably documented to the officer's superiors who approve loan applications. As a consequence large hierarchical banks will be less likely to invest in screening and monitoring, and thus to lend to financially opaque firms. Empirical work has employed different strategies to identify the impact of bank organization on the employed lending technology. Berger et al. (2005a, 2005b) for example start from the presumption that large banks are more hierarchical. They show that smaller SMEs borrow from smaller banks and that while smaller banks do increasingly use credit scoring methods, they still have stronger relationships with their borrowers. Others have more direct proxies for hierarchy by employing the number of decision layers within a bank. ${ }^{4}$ Liberti and Mian (2009) find that greater hierarchical distance between the information collecting agent and the hierarchical unit that decides on loans leads to less reliance on

\footnotetext{
${ }^{3}$ Recent experimental results indicate that information sharing disciplines borrowers to repay their loans (Brown and Zehnder, 2007). Cross-country evidence, supports the conjecture that information sharing improves credit availability at the aggregate level (Jappelli and Pagano, 2002; Djankov, McLiesh, and Shleifer, 2007) and the firm level (Brown, Jappelli, and Pagano, 2009).

${ }^{4}$ Liberti (2005), for example, studies how changes in a bank's organizational structure affect the incentives of account managers to collect soft information and to employ it in the pricing of loans. He finds that account managers who receive more authority are more inclined to collect and use soft information.
} 
subjective information and more on objective information. Degryse, Laeven and Ongena (2009) find that more hierarchical banks specialize more in transparent firms and employ a more uniform loan pricing strategy. We contribute to this literature by investigating how bank size and expertise impacts on credit constraints of start-up firms and whether this impact varies for high-tech as opposed to low-tech firms. Our results suggest that start-up firms- both low-tech and high-tech face less credit constraints when their main bank is small. We do not find such an effect for bank expertise.

The remainder of the paper is organized as follows. Section 2 presents the data and our methodology. Section 3 describes the results of our empirical analysis using the KfW/ZEW start-up panel. Section 4 concludes.

\section{Data \& Methodology}

Our analysis is based on the three initial waves (2008, 2009 and 2010) of the KfW/ZEW Start-up panel. This survey contains information on the financing, economic activity and ownership of start-up firms in Germany ${ }^{5}$. The survey includes subsequent waves allowing to investigate the development of newly founded firms over time.

\section{$\underline{\text { Panel Structure }}$}

The sample consists of 9,715 firms among which 4,972 are observed once, 2,902 are observed twice and 2,309 are observed in all three waves (see Table 1, panel A). This yields a total of 15,000 firm-year observations (see Table 1, panel B). Note that in the initial 2008 wave, firms which started operations in either 2005, 2006 or 2007 were surveyed. This implies that with our three waves of data, our dataset includes firms ageing one to five years. Financing information is only provided for the year of observation. Therefore, financing information in the firm's initial year is not given for those with delayed entry into the Start-up Panel.

Panel B of Table 1 shows that 39\% of all observations are for High-Tech firms. We distinguish between High-Tech firms and Low-Tech firms defined according to average

\footnotetext{
${ }^{5}$ The survey oversamples start-ups in High-Tech industries and firms which receive subsidized funding from the German Kreditanstalt für Wiederaufbau (KfW). KFW is a business development bank at the federal level in Germany which is government owned and was initiated to promote Germany at home as well as abroad. In addition to the provision of subsidized loans the KfW also manages subsidies assigned by the federal employment agency (Bundesagentur für Arbeit). For robustness checks all regressions are estimated without firms stratified based on their KfW characteristic.
} 
expenditures on research and development (R\&D) per industry. In particular, High-Tech firms are active in industries with average $R \& D$ expenditures exceeding $12 \%$ of annual sales. Low-Tech firms are active in industries with average $R \& D$ expenditures below this threshold. ${ }^{6}$

\section{Table 1. Structure of the KfW/ZEW- Start-up Panel}

Panel A and Panel B report the number of observations by year of observation and the firms' year of foundation. The year of observation $(2007,2008,2009)$ is the year prior to each survey wave $(2008,2009,2010)$. Financial information is provided for the year of observation.

Panel A. Firm observations

\begin{tabular}{cr|rrrrr}
\hline \hline & \multicolumn{5}{|c}{ Year of foundation } \\
Years of observation & Total & 2005 & 2006 & 2007 & 2008 & 2009 \\
\hline $2007,2008,2009$ & 2,309 & 766 & 845 & 698 & 0 & 0 \\
$2007,2008,----$ & 1,108 & 332 & 409 & 367 & 0 & 0 \\
$----, 2008,2009$ & 1326 & 0 & 127 & 306 & 893 & 0 \\
$2007,----, 2009$ & 468 & 160 & 164 & 144 & 0 & 0 \\
$2007,---,---$ & 1,559 & 516 & 524 & 519 & 0 & 0 \\
$----, 2008,---$ & 853 & 0 & 101 & 211 & 541 & 0 \\
,,------- 2009 & 2,092 & 0 & 0 & 186 & 396 & 1,510 \\
\hline Total & 9,715 & 1,774 & 2,170 & 2,431 & 1,830 & 1,510 \\
\hline \hline
\end{tabular}

Panel B. Firm-year observations

\begin{tabular}{|c|c|c|c|c|c|c|}
\hline \multirow[b]{2}{*}{ Year of observation } & \multirow[b]{2}{*}{ Total } & \multicolumn{5}{|c|}{ Year of foundation } \\
\hline & & 2005 & 2006 & 2007 & 2008 & 2009 \\
\hline 2007 & 5,185 & 1,682 & 1,850 & 1,653 & 0 & 0 \\
\hline 2008 & 4,907 & 1,043 & 1,355 & 1,391 & 1,118 & 0 \\
\hline 2009 & 4,908 & 752 & 908 & 1,062 & 1,006 & 1,180 \\
\hline Total & 15,000 & 3,477 & 4,113 & 4,106 & 2,124 & 1,180 \\
\hline High-Tech share & 0.39 & 0.40 & 0.40 & 0.38 & 0.39 & 0.38 \\
\hline
\end{tabular}

\footnotetext{
${ }^{6}$ We choose to classify firm innovativeness according to industry-level R\&D activity rather than firm-level in order to mitigate issues of endogeneity of $R \& D$ to bank finance. However, using information on firm-level R\&D from the ZEW/KfW Start-up Panel to classify firms as innovative (have at least one full-time employee engaged in R\&D) versus non-innovative (no full-time employee engaged in R\&D) yields similar patterns of bank finance as presented in Panel C of Table 2.
} 


\section{$\underline{\text { Bank Finance }}$}

We employ three dependent variables, each capturing different aspects of firm financing using banks. Bank use is a dummy which is 1 for all firms that use bank finance for working capital or new investment in a particular year. Bank share is the share of working capital and new investment financed by banks in a particular year. The other sources of external financing are start-up grants for previous unemployed entrepreneurs by the federal employment agency, loans provided by family members or friends, mezzanine capital, and external equity ${ }^{7}$. Both Bank use and Bank share are measures of the usage of bank finance. Finally, Bank difficulties is a dummy variable which equals one when a firm states that it had difficulties in getting bank finance for working capital or new investment in a given year. We interpret this variable as an inverse measure of credit availability. Table 2 presents summary statistics for our three dependent variables. Panel A suggests that in 26 percent of the firmyears, firms use bank finance with an average share of bank finance to total finance of 9 percent. Also, firms report difficulties in accessing bank finance in around 15\% of the firmyears.

Panel B of Table 2 reports sample means for our dependent variables by firm age. Interestingly, the share of firms which use bank finance declines over time from 35 percent in the first year to 24 percent in the $5^{\text {th }}$ year. This decline may be driven by lower needs for new investment and the ability to finance working capital with retained earnings after the initial start-up phase. However, it may also be driven by attrition. Firms which require external finance may be less likely to survive the initial start-up phase and thus disappear from the survey. To control for demand and attrition effects, the right hand side of Panel B reports the means of our three dependent variables only for the subsample of firms which Require external finance. We define these firms as those which either use external finance (bank finance or other sources of external financing) and/or firms which report difficulties in accessing external finance. The data presented in Panel B suggests that once we control for attrition and the demand for external finance, the use of bank finance hardly changes over time. In their first year of existence, 66 percent of firms that require external finance use bank finance, while among the five-year-old firms 68 percent do so. The share of bank finance to total finance also remains fairly stable over time for firms that demand external finance, while the share of firms reporting difficulties in accessing bank finance increases with firm age. Panel B also reports the use of other sources of external finance by firm age. We learn

\footnotetext{
${ }^{7}$ External equity either is Private Equity, Venture Capital, capital from business angels or capital from shares sold to others. Details of other sources of external financing for our sample of firms are provided in Appendix 1.
} 
that the federal employment agency is most important in the first year and considerably drops thereafter. The other sources remain fairly stable in firm age.

\section{Table 2. Indicators of bank finance}

Panel A presents the summary statistics of the dependent variables. Panel B presents mean values by firm age. Panel C presents mean values by statistics related to industry classification which is based on the firm's product with the largest sales potential. A list of the industry coding is provided in the Appendix. In Panel B and Panel $\mathrm{C}$ we report means for all firms in the dataset, as well as for a subsample of firms seeking external finance. The later is restricted to firms that either use external finance and / or stated difficulties in accessing external finance.

Panel A - Summary statistics

\begin{tabular}{|c|c|c|c|c|c|c|c|}
\hline & $\begin{array}{r}\text { Firm-year } \\
\text { obs. }\end{array}$ & mean & median & $\min$ & $\max$ & Definition & Source \\
\hline Bank use & 15,000 & 0.26 & 0 & 0 & 1 & $\begin{array}{l}1 \text { if firm uses bank loan or } \\
\text { overdraft; } 0 \text { otherwise }\end{array}$ & SuP \\
\hline Bank share & 12,104 & 0.09 & 0 & 0 & 1 & $\begin{array}{l}\text { Ratio of bank finance to total } \\
\text { financing volume }\end{array}$ & SuP \\
\hline $\begin{array}{l}\text { Bank } \\
\text { difficulties }\end{array}$ & 14,988 & 0.15 & 0 & 0 & 1 & $\begin{array}{l}1 \text { if firm reports difficulties } \\
\text { accessing bank finance; } 0 \\
\text { otherwise }\end{array}$ & SuP \\
\hline
\end{tabular}

Panel B - Mean values by firm age and demand for external finance

\begin{tabular}{lrrrrr|rrrrr}
\hline \hline & \multicolumn{9}{c|}{ All firms } & \multicolumn{5}{c}{ Firms seeking external finance } \\
\cline { 2 - 10 } $\begin{array}{l}\text { Firm age in } \\
\text { years }\end{array}$ & 1 & 2 & 3 & 4 & 5 & 1 & 2 & 3 & 4 & 5 \\
\hline Bank use & 0.35 & 0.25 & 0.21 & 0.21 & 0.24 & 0.66 & 0.65 & 0.64 & 0.64 & 0.68 \\
Bank share & 0.13 & 0.08 & 0.07 & 0.07 & 0.10 & 0.24 & 0.21 & 0.20 & 0.20 & 0.25 \\
$\begin{array}{l}\text { Bank } \\
\text { difficulties }\end{array}$ & 0.17 & 0.14 & 0.14 & 0.15 & 0.16 & 0.32 & 0.37 & 0.42 & 0.44 & 0.46 \\
\hline $\begin{array}{l}\text { Firm-year } \\
\text { observations }\end{array}$ & 3,951 & 4,247 & 4,099 & 1,951 & 752 & 2,115 & 1,625 & 1,366 & 645 & 268 \\
\hline \hline
\end{tabular}

Panel C - Mean values by industry and demand for external finance

\begin{tabular}{|c|c|c|c|c|c|c|}
\hline & \multicolumn{3}{|c|}{ All firms } & \multicolumn{3}{|c|}{ Firms seeking external finance } \\
\hline & $\begin{array}{r}\text { All } \\
\text { industries }\end{array}$ & Low-tech & High-Tech & $\begin{array}{r}\text { All } \\
\text { industries }\end{array}$ & Low-tech & High-Tech \\
\hline Bank use & 0.26 & 0.30 & 0.19 & 0.65 & 0.69 & 0.57 \\
\hline Bank share & 0.09 & 0.11 & 0.06 & 0.22 & 0.24 & 0.17 \\
\hline Bank difficulties & 0.15 & 0.16 & 0.14 & 0.38 & 0.36 & 0.41 \\
\hline Firm-year observations & 15,000 & 9,129 & 5,871 & 6,019 & 4,015 & 2,004 \\
\hline
\end{tabular}

In Panel C of Table 2 we report summary statistics of our dependent variables for LowTech and High-Tech firms separately. Means are presented for all firms as well for the subsample of firms which seek external finance. Focusing on the latter subsample of firms, 
Panel C shows that there is a marked difference in access to bank finance between High-Tech and Low-Tech firms. Considering only those firms that require external finance we find that 69 percent of Low-Tech firms report that they use bank finance while only 57 percent of High-Tech firms do so. The Bank Share of total firm financing is 24 percent for Low-Tech firms compared to 17 percent for High-Tech firms. Finally, 41 percent of High-Tech firms report Bank difficulties in accessing bank finance, while only 36 percent of Low-Tech firms do so. ${ }^{8}$

\section{External credit rating}

We match the data from the ZEW/KfW Start-up Panel with information provided by the credit bureau Creditreform to yield external credit rating information for each firm. Creditreform is the biggest database on German companies with more than 3.6 million entries. It is the leading source of information on creditworthiness of small firms. While Germany has also a public credit registry organized by the Bundesbank, it contains only information on large exposures (more than $€ 1.5$ million), a threshold largely exceeding the loans to start-up firms. From the Creditreform database we extract for each firm and each year an indicator of whether an external credit rating is provided for the firm, and if so, how the firm is rated. Similar to the credit scores provided e.g. by Dun \& Bradstreet, the score provided by Creditreform is based on past payment behavior on trade credit from suppliers as well as utilities. The information on payment behavior is enhanced with a subjective assessment by Creditreform of the firm's future capability to honor credit relations. The latter assessment is provided by the analyst investigating the firm. It is based on the full set of information regarding the firm including e.g. order situation. As illustrated in Table 3, Panel A, each firm is rated on a scale of 1 to 6 . In line with the classification by Creditreform we code the rating classes 1 (advise against a business relation), 2 (Business relation is a matter of trust) and 3 (Business relation at discretion) as Bad rating. Rating class 4 (Business relation approvable) is coded as Fair rating, while classes 5 (Business relation approved) and 6 (Business relation supported) are coded as Good rating.

Table 3, Panel B reports the frequency by firm age of the availability of a credit rating and the rating type - no rating, bad, fair and good. As past payment behavior on trade credit and utilities is a key element of the credit rating, it is not surprising that only a minority of

\footnotetext{
${ }^{8}$ By contrast to bank finance Appendix 1 shows that High-Tech firms are more likely to use external equity (11\%) and mezzanine capital (3\%) than Low-Tech firms ( $4 \%$ and $1 \%$ respectively).
} 
firms (1.7 percent) are rated in their first year of existence. The data suggests that the assignment of a credit rating in the first year of existence is endogenous to firm payment behavior: Ratings assigned in the first year of existence are much more likely to be bad ratings $(17.6 \%)$ than ratings assigned later. The share of rated firms increases fast between the age of two and four years, so that among four year old firms only $9 \%$ have no rating.

Table 3. Credit Rating

Panel A reports the classification. Panel B reports the availability of credit ratings and the distribution of credit ratings for those firms which have a credit rating by firm age.

Panel A. Rating classification

\begin{tabular}{|c|c|c|}
\hline Rating class & Classification & Code \\
\hline 1 & Advise against a business relation. & \multirow{3}{*}{ ర్రి } \\
\hline 2 & Business relation is a matter of trust. & \\
\hline 3 & Business relation is discretionary. & \\
\hline 4 & Business relation is approvable. & : \\
\hline 5 & Business relation approved. & \multirow{2}{*}{$\begin{array}{l}\text { 밍 } \\
\text { 음 }\end{array}$} \\
\hline 6 & Business relation supported. & \\
\hline
\end{tabular}

Panel B. Availability and type of credit rating

\begin{tabular}{cr|ccr}
\hline \hline & \multicolumn{2}{c|}{$\begin{array}{c}\text { Rating } \\
\text { available (\%) }\end{array}$} & \multicolumn{3}{|c}{ Frequeny of rating if available (\%) } \\
\hline 1 & 1.7 & Bad & Fair & Good \\
\hline 2 & 28.8 & 17.6 & 44.7 & 37.1 \\
3 & 70.4 & 8.0 & 57.4 & 34.6 \\
4 & 90.6 & 4.6 & 54.3 & 41.1 \\
5 & 94.6 & 4.8 & 53.5 & 41.7 \\
\hline Total & 44.4 & 5.5 & 52.6 & 41.9 \\
\hline \hline
\end{tabular}

\section{Size and expertise of main bank}

The Creditreform database also provides information on the main bank relation of each firm. Creditreform gathers information on bank-firm relationships from firm letterheads, invoices and financial statements. We classify each firm's main bank according to the size of that bank and how focused the lending of that bank is in the firm's industry. As our dataset does not provide us with information on the total loan portfolio of each bank we approximate Bank size by the total labor force employed by all firms the bank serves as a main bank. We 
use two measures to capture the industry focus of the firm's main bank. The variable Bank expertise captures the total number of firms in the same industry which the bank serves as a main bank. The rationale behind this indicator is that the expertise of the bank with respect to underwriting loans in a particular industry is related to the absolute number of loans it makes in this industry. The variable Bank specialization measures the share of the bank's activities which are in the firm's industry. As we do not have information on bank loan portfolios we use the total labor force of firms served by the bank in the industry relative to the total labor force of all firms served by the bank as our measure of specialization of the bank in that industry. Thus while Bank expertise measures the absolute expertise of the bank in an industry, the variable Bank specialization is a measure of relative specialization in a particular industry.

For each firm we not only have information on the main bank but also the corresponding bank branch is identified. We therefore are in a position to measure Bank size, Bank expertise and Bank specialization at the national, state or regional level. Motivated by the conjecture that in large, nationwide German banks credit decisions are made at either branch, regional or state level, but hardly at the national level, we calculate all three indicators at the state level. ${ }^{9}$ Table 4, Panel A, provides definitions and summary statistics for all our key explanatory variables.

\section{Control variables}

In our multivariate analysis we control for a range of firm characteristics which may affect a firm's access to bank finance. Table 4, Panel B, presents definitions and summary statistics for all control variables. We control for Firm age, and firm size (Sales, number of Employees). With respect to firm governance, we control for whether there is a Management team or a sole manager, the firm is a Limited company or not, whether at least one manager is a Master craftsman or not, whether at least one manager has a University degree, as well as the Entrepreneurial experience of the management. With respect to firm financing, we control for whether the firm has Private equity investment ${ }^{10}$, and whether the firm or the owner has Real estate (which could be used as collateral). We control for whether the firm is a Manufacturing or alternatively a service firm in order to account for different demand for

\footnotetext{
${ }^{9}$ Nationwide banks are split at the bank-clearing level 2 of the German Bundesbank which roughly corresponds to the state level.

${ }^{10}$ Private equity is a dummy variable which is 1 if the firm has private equity in any year within our observation period. We also run (unreported) regressions dropping private equity as explanatory variable, or including lagged private equity. Results are robust to these alterations.
} 
credit and availability of tangible pledgeable assets. We further control for the riskiness of the business with the industry-level Exit rate and the district-level Unemployment rate in each year. Finally we include year dummies (for 2007 and 2008, with 2009 as reference) to account for country-wide level changes in access to finance during the crisis.

\section{Table 4. Explanatory variables}

This table presents definitions, sources and summary statistics for our explanatory variables, with the main explanatory variables presented in Panel A and control variables presented in Panel B. Data sources are either the KfW/ZEW Start-up Panel (SuP), Mannheim Enterprise Panel (MUP), or Bank Panel (BP). Bank size, Bank expertise and Bank specialization are based on firm-bank relationships, whereby nationwide banks are split roughly at the State level (bank-clearing level 2 according to the German Bundesbank).

Panel A. Main explanatory variables

\begin{tabular}{|c|c|c|c|c|c|c|c|}
\hline & Obs & Mean & Median & Min & Max & Definition & Source \\
\hline \multicolumn{8}{|c|}{ Innovation } \\
\hline High-tech & 15,000 & 0.39 & 0 & 0 & 1 & $\begin{array}{l}1 \text { if firm is in a High-Tech industry; } 0 \\
\text { otherwise }\end{array}$ & SuP \\
\hline \multicolumn{8}{|c|}{ Rating } \\
\hline No rating & 15,000 & 0.56 & 1 & 0 & 1 & $\begin{array}{l}1 \text { if credit rating is not available in } \\
\text { January of the year of observation; } 0 \\
\text { otherwise }\end{array}$ & MUP \\
\hline Bad rating & 15,000 & 0.02 & 0 & 0 & 1 & $\begin{array}{l}1 \text { if rating category equals } 1 \text { to } 3 ; 0 \\
\text { otherwise }\end{array}$ & MUP \\
\hline Fair rating & 15,000 & 0.24 & 0 & 0 & 1 & 1 if rating category equals $4 ; 0$ otherwise & MUP \\
\hline Good rating & 15,000 & 0.18 & 0 & 0 & 1 & $\begin{array}{l}1 \text { if rating category equals } 5 \text { or } 6 ; 0 \\
\text { otherwise }\end{array}$ & MUP \\
\hline \multicolumn{8}{|c|}{ Bank characteristics } \\
\hline Bank size & 11,836 & 113,719 & 30,854 & 10 & $1,704,219$ & $\begin{array}{l}\text { Total labor force of firms with the same } \\
\text { main bank relationship. }\end{array}$ & $\begin{array}{r}\text { BP } \\
\text { and } \\
\text { MUP }\end{array}$ \\
\hline $\begin{array}{l}\text { Bank } \\
\text { expertise }\end{array}$ & 11,836 & 9,414 & 2,197 & 2 & 366,984 & $\begin{array}{l}\text { Number of firms with the same main } \\
\text { bank relation and the same industry } \\
\text { coding. }\end{array}$ & $\begin{array}{r}\text { BP } \\
\text { and } \\
\text { MUP }\end{array}$ \\
\hline $\begin{array}{l}\text { Bank } \\
\text { specialisation }\end{array}$ & 11,836 & 0.12 & 0.10 & 0.00 & 0.80 & $\begin{array}{l}\text { Total labor force of firms with the same } \\
\text { main bank relation and the same } \\
\text { industry coding divided by total labor } \\
\text { force of firms with the same main bank } \\
\text { relation. }\end{array}$ & $\begin{array}{r}\text { BP } \\
\text { and } \\
\text { MUP }\end{array}$ \\
\hline
\end{tabular}

\section{Methodology}

Our first hypothesis is that banks are less likely to condition credit decisions on external credit ratings when they are dealing with High-Tech as opposed to Low-Tech firms. To test this hypothesis we first examine the pooled cross-sectional model [1]. In this model $B F_{i, j, t}$ is an indicator of access to bank finance for firm $i$ in industry $j$ and for year $t$. As explanatory 
variables we employ year specific intercepts $\alpha_{t}$, indicators of credit rating $C R_{i, t}$ as well as firm-level, industry-level and district-level controls $F_{i, t}$. Our main interest in this model is on the coefficients $\beta_{2}$ which capture whether credit ratings have a differential impact on credit availability for the subsample of High-Tech (HT) as opposed to the subsample of Low-Tech firms.

$$
B F_{i, j, t}=\alpha_{t}+\beta_{1} \cdot C R_{i, t}+\beta_{2} \cdot H T_{i} \cdot C R_{i, t}+\beta_{3} \cdot F_{i, t}+\epsilon_{i, j, t}
$$

Model [1] does not take advantage of the panel dimension of our data to control for timeinvariant heterogeneity across firms. We complement model [1] with a panel analysis that focuses on those firms which received their initial credit rating at the age of 2-4 years. ${ }^{11}$ Among these firms we compare those firms which initially received a Bad rating as opposed to those firms that received a Fair rating or a Good rating. As captured by the interaction term $H T_{i} * C R_{i, t}$ in model [2] we examine whether among initially rated firms the difference in the share of bank loans to total finance across rating classes differs for High-Tech as opposed to Low-Tech firms.

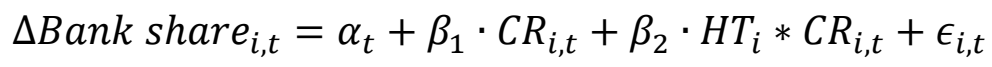

for firms with $C R_{t-1}=$ missing

Our second hypothesis is that the bank with which the firm has its main bank relationship is more important in determining the access to finance for High-Tech as opposed to LowTech firms. Both Bank size and industry focus (Bank expertise, Bank specialization) may play a role. Berger et al. (2005) for example employ bank size as proxy for organizational complexity. Larger banks are more hierarchically organized and therefore may rely less on soft information in their decision making (Stein (2002)). These negative impacts of bank size are expected to be more relevant for high-tech sectors as these require more soft information in loan granting decisions. Expertise or relative specialization in a particular industry may

\footnotetext{
${ }^{11}$ As displayed in Table 3 over 95\% of firms receive their first rating in this period. We exclude firms which receive their initial rating already in their first year of existence as well as those that are not rated until their fifth year in order to mitigate selection effects.
} 
alleviate financing constraints. We conjecture that expertise or specialization is more important for High-tech firms as opposed to Low-Tech firms.

We examine the impact of the main bank relationship on credit access for High-Tech as opposed to Low-Tech firms with the pooled cross-sectional model [3]. Again, $B F_{i, j, t}$ is an indicator of access to bank finance for firm $i$ in industry $j$ and for year $t$. As explanatory variables we employ year specific intercepts $\alpha_{t}$, indicators of the main bank relationship of the firm $B R_{i}$ as well as firm-level, industry-level and district-level controls $F_{i, t}$. Our main focus of interest in this model is again on establishing whether the coefficients $\beta_{2}$ capture differential impacts of bank relationships for the subsample of High-Tech as opposed to the subsample of Low-Tech firms.

[3] $\quad B F_{i, j, t}=\alpha_{t}+\beta_{1} \cdot B R_{i}+\beta_{2} \cdot H T_{i} \cdot B R_{i}+\beta_{3} \cdot F_{i, t}+\epsilon_{i, j, t}$ 


\section{Results}

Tables 5-8 present the results of our multivariate analysis. In tables (5-7) we report results for all firms as well as for the subsample of firms that seek external finance, while in table 8 we report results only for the subsample of firms that seek external finance. By excluding those firms that do not require external financing for investment or operations we try to disentangle supply side effects from demand side drivers of the use of bank finance. However, because there are other sources of external finance, results reported for bank finance (i.e., Bank use and Bank share) may also be driven by demand. Therefore, we only conclude that there is a credit availability effect when we find significant results in the regression for Bank difficulties.

\section{Firm innovation and bank finance}

Table 5 presents pooled cross-sectional estimates examining the relation between firmcharacteristics and access to bank finance. For each of our three dependent variables Bank use, Bank share and Bank difficulties we present two specifications: Columns (1-3) present results for all firms while columns (4-6) present results for the subsample of firms that seek external finance. The table reports OLS estimates for each specification, with standard errors clustered at the firm level reported in parentheses. Therefore the results for the dummy variables Bank use and Bank difficulties should be interpreted within the context of a linear probability model.

The Table 5 results suggest that High-Tech firms are less likely to use bank finance and are more likely to experience difficulties in accessing bank finance than Low-Tech firms. The coefficient of the dummy variable High-Tech in columns (1-2) suggests that considering the full sample of firms High-Tech firms are 9.4 percentage points less likely to use bank finance than Low-Tech firms and have on average a share of bank finance that is 4.7 percentage 
points lower. The results reported in columns (4-5) for the subsample of firms which seek external finance show a slightly larger difference between High-Tech and Low-Tech firms. The column (6) results show further that, among those firms that seek external finance, HighTech firms are 5 percentage points more likely to report difficulties in getting bank finance than Low-Tech firms. Table 2 shows that among the firms that seek external finance, 65\% use bank finance, the average bank share of external financing is $22 \%$ and the share of firms that report difficulties getting bank finance is $38 \%$. Compared to these sample averages the estimated differences between High-Tech and Low-Tech firms are not only statistically, but also economically significant.

Focusing on the column (4-6) estimates, the results on Firm age suggest firms are less likely to use bank finance and more likely to experience difficulties in getting bank finance as they grow older, while High-Tech firms are also more likely to experience difficulties as they become older. Larger firms (Employees, Sales) are more likely to use bank finance. Limited liable companies use less bank finance and are more likely to face difficulties getting bank finance. Private equity investment is associated with lower shares of bank financing, but also with less difficulties in getting bank finance. This confirmed our conjecture that firms which receive private equity funding are less reliant on bank finance. Firms with better educated managers, i.e. Master craftsman and University degree are more likely to use bank credit and less likely to experience difficulties getting bank finance. Prior experience of the entrepreneur (Experience) is associated with less access to bank finance. The latter variable may capture the effect of the manager having failed previous ventures. Finally, entrepreneurs who own real estate, and thus have collateral to post, are more likely to use bank finance. However, the availability of such outside collateral does not seem to diminish the likelihood of facing difficulties in getting bank finance. 
Table 5. Innovation and bank finance: Cross-sectional estimates

All standard errors clustered by firms are reported in parentheses below the coefficients. Statistical significance at the $1 \%, 5 \%$, and $10 \%$ level is indicated by ***, **, and *, respectively. See Tables 2 and 4 for definitions of all variables.

\begin{tabular}{|c|c|c|c|c|c|c|}
\hline \multirow{4}{*}{$\begin{array}{r}\text { Firms } \\
\text { Dependent variable } \\
\text { Industry } \\
\text { Model }\end{array}$} & \multicolumn{3}{|c|}{ All firms } & \multicolumn{3}{|c|}{ Firms seeking external finance } \\
\hline & Bank use & Bank share & Bank difficulties & Bank use & Bank share & Bank difficulties \\
\hline & HT \& LT & HT \& LT & $\mathrm{HT} \& \mathrm{LT}$ & HT \& LT & HT \& LT & HT \& LT \\
\hline & (1) & $(2)$ & (3) & $(4)$ & (5) & (6) \\
\hline \multirow[t]{2}{*}{ High-Tech } & $-0.094 * * *$ & $-0.047^{* * *}$ & -0.011 & $-0.109 * * *$ & $-0.067 * * *$ & $0.048 * * *$ \\
\hline & $(0.01)$ & $(0.00)$ & $(0.01)$ & $(0.02)$ & $(0.01)$ & $(0.02)$ \\
\hline \multirow[t]{2}{*}{ Firm age } & $-0.057^{* * *}$ & $-0.024 * * *$ & $-0.011 * * *$ & $-0.016 * * *$ & $-0.014 * * *$ & $0.047 * * *$ \\
\hline & $(0.00)$ & $(0.00)$ & $(0.00)$ & $(0.01)$ & $(0.00)$ & $(0.01)$ \\
\hline \multirow[t]{2}{*}{ Management team } & 0.016 & $0.009 *$ & -0.002 & 0.012 & 0.013 & -0.017 \\
\hline & (0.01) & $(0.01)$ & $(0.01)$ & $(0.02)$ & $(0.01)$ & $(0.02)$ \\
\hline \multirow[t]{2}{*}{ Employees } & $0.006^{* * *}$ & $0.003 * * *$ & $0.001 * *$ & $0.004 * * *$ & $0.003 * * *$ & -0.001 \\
\hline & $(0.00)$ & $(0.00)$ & $(0.00)$ & $(0.00)$ & $(0.00)$ & $(0.00)$ \\
\hline \multirow[t]{2}{*}{ Limited company } & $-0.050 * * *$ & $-0.014 * * *$ & $0.025^{* * *}$ & $-0.068 * * *$ & -0.012 & $0.091 * * *$ \\
\hline & $(0.01)$ & $(0.01)$ & $(0.01)$ & $(0.02)$ & $(0.01)$ & $(0.02)$ \\
\hline \multirow[t]{2}{*}{ Sales } & $0.004 * * *$ & 0.001 & $0.002 * * *$ & $0.006 * * *$ & 0.001 & 0.002 \\
\hline & $(0.00)$ & $(0.00)$ & $(0.00)$ & $(0.00)$ & $(0.00)$ & $(0.00)$ \\
\hline \multirow[t]{2}{*}{ Private equity } & $0.215^{* * *}$ & $0.029 * * *$ & $0.108 * * *$ & $-0.052^{*}$ & $-0.072 * * *$ & $-0.104 * * *$ \\
\hline & $(0.02)$ & $(0.01)$ & $(0.02)$ & $(0.03)$ & $(0.01)$ & $(0.03)$ \\
\hline \multirow[t]{2}{*}{ Master craftsman } & $0.041 * * *$ & $0.014 * *$ & $-0.024 * * *$ & $0.090 * * *$ & $0.034 * * *$ & $-0.062 * * *$ \\
\hline & $(0.01)$ & $(0.01)$ & $(0.01)$ & $(0.02)$ & $(0.01)$ & $(0.02)$ \\
\hline \multirow[t]{2}{*}{ University degree } & -0.002 & 0.001 & $-0.026 * * *$ & $0.040 * *$ & 0.015 & $-0.042 * *$ \\
\hline & $(0.01)$ & $(0.00)$ & $(0.01)$ & $(0.02)$ & $(0.01)$ & $(0.02)$ \\
\hline \multirow[t]{2}{*}{ Experience } & $-0.047^{* * *}$ & $-0.030 * * *$ & $0.054^{* * *}$ & $-0.086 * * *$ & $-0.050 * * *$ & $0.133^{* * *}$ \\
\hline & (0.02) & $(0.01)$ & $(0.01)$ & $(0.02)$ & $(0.01)$ & $(0.02)$ \\
\hline \multirow[t]{2}{*}{ Real estate } & $0.031^{* *}$ & $0.019 * *$ & 0.006 & $0.039 *$ & $0.038 * *$ & -0.012 \\
\hline & $(0.02)$ & $(0.01)$ & $(0.01)$ & $(0.02)$ & $(0.02)$ & $(0.03)$ \\
\hline \multirow[t]{2}{*}{ Manufacturing } & $0.042^{* * *}$ & $0.020 * * *$ & $0.030 * * *$ & 0.013 & $0.016 *$ & 0.012 \\
\hline & (0.01) & $(0.01)$ & $(0.01)$ & $(0.01)$ & $(0.01)$ & $(0.02)$ \\
\hline \multirow[t]{2}{*}{ Exit rate } & $-0.091 * * *$ & $-0.049 * * *$ & $-0.062 * * *$ & -0.015 & $-0.031 * * *$ & $-0.072 * * *$ \\
\hline & $(0.01)$ & $(0.01)$ & $(0.01)$ & $(0.02)$ & $(0.01)$ & $(0.02)$ \\
\hline \multirow[t]{2}{*}{ Unemployment } & $-0.005^{* * *}$ & $-0.002 * * *$ & 0.001 & $-0.011 * * *$ & $-0.005^{* * *}$ & 0.002 \\
\hline & $(0.00)$ & $(0.00)$ & $(0.00)$ & $(0.00)$ & $(0.00)$ & $(0.00)$ \\
\hline \multirow[t]{2}{*}{ Year 2007} & $-0.052 * * *$ & $-0.049 * * *$ & $-0.020 * * *$ & $-0.051 * * *$ & $-0.081 * * *$ & -0.023 \\
\hline & $(0.01)$ & $(0.00)$ & $(0.01)$ & $(0.01)$ & $(0.01)$ & $(0.01)$ \\
\hline \multirow[t]{2}{*}{ Year 2008} & 0 & -0.001 & $0.003^{* *}$ & -0.004 & $-0.003^{* *}$ & $0.006 * *$ \\
\hline & $(0.00)$ & $(0.00)$ & $(0.00)$ & $(0.00)$ & $(0.00)$ & $(0.00)$ \\
\hline \multirow[t]{2}{*}{ Constant } & $0.441^{* * *}$ & $0.202 * * *$ & $0.133^{* * *}$ & $0.761 * * *$ & $0.351 * * *$ & $0.199 * * *$ \\
\hline & $(0.03)$ & $(0.01)$ & $(0.02)$ & $(0.04)$ & $(0.03)$ & $(0.04)$ \\
\hline Observations & 15000 & 12105 & 15994 & 6019 & 5015 & 6113 \\
\hline Method & OLS & OLS & OLS & OLS & OLS & OLS \\
\hline log likelihood & -8468.76 & 1897.6 & -5907.86 & -3942.41 & -656.09 & -4152.39 \\
\hline
\end{tabular}


Considering the estimates in columns (1-3) Manufacturing firms seem to use more bank finance than service firms, but are also likely to experience difficulties in getting bank finance. However, these results seem to be driven by differences in credit demand across industries: Considering only those firms that seek external finance the estimates in columns (4-6) suggest similar access to bank credit for Manufacturing and service orientated firms.

\section{Credit rating and bank finance}

Table 6 presents our estimations of Equation (1) in which we examine the relation between the external credit rating of firms and their use and access to bank finance. We run three specifications, one for each of our three dependent variables. We do this again for the full sample of firms (columns 1-3) as well as for the firms seeking external finance (columns 4-6). We report OLS estimates for all coefficients, with clustered standard errors in parentheses.

In all specifications the variables of interest are the dummy variables No rating, Bad rating, Fair rating and Good rating, and the interaction terms of High-Tech with the rating dummies. The reference group in all specifications are Low-Tech firms without a credit rating. All models include a full set of firm-level control variables, interactions of High-Tech with the firm controls and year dummies. For expositional reasons the estimates of the control variables are not presented in the table.

The results presented in Table 6 suggest that Low-Tech firms which have a Bad rating are less likely to use bank finance, and are more likely to experience difficulties in getting bank finance than firms with either a Good rating, Fair rating, or No rating (the omitted category). The effect is economically important as shown in columns 4-6 for the subsample of firms 
which seek external finance. A Low-Tech firm with a bad rating is 25.7 percentage points less likely to use bank finance and 31 percentage points more likely to face bank difficulties than a Low-Tech firm with no rating. Tests for equality of the coefficients No rating, Fair Rating and Good rating also suggest that in the Low-Tech industry there is no difference in access to finance between firms which have no, fair or good ratings. Similar tests show that the same pattern holds for High-Tech firms. Thus among the start-up firms in our sample it appears that firms without a credit rating are treated as if they have a good or fair rating. This behavior by banks seems very reasonable given that at most $5 \%$ of the firms actually do get a bad credit rating, when they are rated (Table 3, Panel B).

\section{Table 6. Credit rating and bank finance: Cross-sectional estimates}

All models include a fulls set of firm-level control variables and year dummies. All standard errors clustered by firms are reported in parentheses below the coefficients. Statistical significance at the $1 \%, 5 \%$, and $10 \%$ level is indicated by ***, **, and *, respectively. See Tables 2 and 4 for definitions of all variables.

\begin{tabular}{|c|c|c|c|c|c|c|}
\hline \multirow{4}{*}{$\begin{array}{r}\text { Firms } \\
\text { Dependent variable } \\
\text { Industry } \\
\text { Model }\end{array}$} & \multicolumn{3}{|c|}{ All firms } & \multicolumn{3}{|c|}{ Firms seeking external finance } \\
\hline & Bank use & Bank share & Bank difficulties & Bank use & Bank share & Bank difficulties \\
\hline & $H T \& L T$ & $\mathrm{HT} \&$ \& LT & $H T \& L T$ & $H T \& L T$ & $H T \& L T$ & HT \& LT \\
\hline & (1) & $(2)$ & (3) & (4) & $(5)$ & (6) \\
\hline \multirow[t]{2}{*}{ Bad rating } & $-0.072 * *$ & -0.012 & $0.162 * * *$ & $-0.257 * * *$ & $-0.062 * *$ & $0.310 * * *$ \\
\hline & $(0.03)$ & $(0.02)$ & $(0.03)$ & $(0.05)$ & $(0.03)$ & $(0.05)$ \\
\hline \multirow[t]{2}{*}{ Fair rating } & -0.008 & 0.002 & 0.013 & -0.006 & 0.008 & $0.050 *$ \\
\hline & $(0.01)$ & $(0.01)$ & $(0.01)$ & $(0.03)$ & $(0.02)$ & $(0.03)$ \\
\hline \multirow[t]{2}{*}{ Good rating } & 0.011 & 0.009 & 0.015 & -0.003 & 0.012 & 0.035 \\
\hline & $(0.02)$ & $(0.01)$ & $(0.01)$ & $(0.03)$ & $(0.02)$ & $(0.03)$ \\
\hline \multirow[t]{2}{*}{$H T^{*}$ No rating } & -0.048 & $-0.049 *$ & 0.043 & 0.004 & 0 & 0.084 \\
\hline & $(0.05)$ & $(0.03)$ & $(0.04)$ & $(0.09)$ & $(0.06)$ & $(0.10)$ \\
\hline \multirow[t]{2}{*}{$H T^{*}$ Bad rating } & -0.002 & -0.018 & -0.036 & 0.022 & 0.052 & -0.134 \\
\hline & $(0.07)$ & $(0.04)$ & $(0.07)$ & $(0.13)$ & $(0.08)$ & $(0.14)$ \\
\hline \multirow[t]{2}{*}{$H T^{*}$ Fair rating } & -0.049 & -0.051 & 0.022 & -0.019 & -0.016 & 0.01 \\
\hline & $(0.06)$ & $(0.03)$ & $(0.05)$ & $(0.11)$ & $(0.07)$ & $(0.11)$ \\
\hline \multirow[t]{2}{*}{$H T^{*}$ Good rating } & -0.073 & $-0.057^{*}$ & 0.02 & 0.001 & 0.016 & 0.042 \\
\hline & $(0.06)$ & $(0.03)$ & $(0.05)$ & $(0.11)$ & $(0.07)$ & $(0.11)$ \\
\hline Observations & 15000 & 12105 & 15994 & 6019 & 5015 & 6113 \\
\hline Firm controls & yes & yes & yes & yes & yes & yes \\
\hline Firm controls * HT & yes & yes & yes & yes & yes & yes \\
\hline Year dummies & yes & yes & yes & yes & yes & yes \\
\hline Method & OLS & OLS & OLS & OLS & OLS & OLS \\
\hline log likelihood & -7945.58 & 2249.77 & -5859.97 & -3623.28 & -482.49 & -4081.02 \\
\hline
\end{tabular}


Contrary to our predictions, none of the interaction terms between High-Tech and the rating variables is significant, suggesting that the impact of the same credit rating on firm access to bank finance does not differ between High-Tech and Low-Tech firms.

The specifications in Table 6 do not take advantage of the panel structure of our data that can allow us to control for unobserved firm heterogeneity. So in Table 7 we perform differences-of-means tests of the changes in Bank share after obtaining a credit rating between Low-Tech and High-Tech firms. We do this for the three credit rating possibilities: when rated for the first time the firm can receive a bad rating, fair rating or good rating. We focus on those firms that received their first credit rating at the age of two, three or four years. As shown in Table 3, over 95 percent of firms receive their first rating during these years. We exclude firms which receive their initial rating already in their first year of existence as well as those that are not rated until their fifth year in order to mitigate selection effects.

Table 7 shows that, when considering all firms (whether seeking external finance or not), a bad rating decreases Bank share by $8 \%$ in the case of Low-Tech firms, while the effect for High-Tech firms is close to zero. Importantly, the difference between the two groups is statistically significant. When restricting the sample to those firms that seek external finance, the magnitudes and signs of the effects are similar though now the difference is not significant, probably due to the lower number of observations and thus less statistical power. These results seem to indicate that a bad rating is less harmful in terms of bank finance for firms in the High-Tech sector than in the Low-Tech sector. Banks seem to rely less on external rating information in their decision making for High-Tech firms. 
Table 7. Credit rating and Bank Finance: Panel analysis

This table presents the effect of a credit rating becoming available on Bank share. In this analysis only firms of 2,3 or 4 years age are considered for which in the previous year no rating was available. The figures present the mean change in Bank share from year t- 1 to year t. Asterix indicate whether the reported mean values are significantly different for firms which received Bad vs. Fair, Fair vs. Good or Bad vs. Good ratings at the * 0.1, ** 0.5, or *** 0.01 level of significance.

\begin{tabular}{|c|c|c|c|c|c|c|c|c|c|c|c|c|c|}
\hline \multirow[b]{2}{*}{ Industry } & & \multicolumn{6}{|c|}{ All firms } & \multicolumn{6}{|c|}{ Firms which require external finance } \\
\hline & & $\begin{array}{c}\text { Bad rating } \\
\text { (1) }\end{array}$ & $\begin{array}{l}\text { Fair rating } \\
\qquad(2)\end{array}$ & $\begin{array}{c}\text { Good rating } \\
\text { (3) }\end{array}$ & $\begin{array}{l}\text { Bad - } \\
\text { Fair } \\
(1)-(2)\end{array}$ & $\begin{array}{l}\text { Fair - } \\
\text { Good } \\
\text { (2)-(3) }\end{array}$ & $\begin{array}{l}\text { Bad - } \\
\text { Good } \\
\text { (1)-(3) }\end{array}$ & $\begin{array}{c}\text { Bad rating } \\
\text { (4) }\end{array}$ & $\begin{array}{c}\text { Fair rating } \\
\text { (5) }\end{array}$ & $\begin{array}{l}\text { Good } \\
\text { rating } \\
\\
(6)\end{array}$ & $\begin{array}{l}\text { Bad - } \\
\text { Fair } \\
\text { (4)-(5) }\end{array}$ & $\begin{array}{l}\text { Fair - } \\
\text { Good } \\
\text { (5)-(6) }\end{array}$ & $\begin{array}{l}\text { Bad - } \\
\text { Good } \\
\text { (4)-(6) }\end{array}$ \\
\hline Low-Tech & $\begin{array}{l}\Delta \text { Bank share } \\
\text { obs. }\end{array}$ & $\begin{array}{c}-0.080 \\
44\end{array}$ & $\begin{array}{c}-0.016 \\
451\end{array}$ & $\begin{array}{c}-0.007 \\
277\end{array}$ & $* *$ & & $* *$ & $\begin{array}{c}-0.055 \\
17\end{array}$ & $\begin{array}{c}0.061 \\
180\end{array}$ & $\begin{array}{c}0.078 \\
120\end{array}$ & * & & $*$ \\
\hline High-Tech & $\begin{array}{l}\Delta \text { Bank share } \\
\text { obs. }\end{array}$ & $\begin{array}{c}0.016 \\
22\end{array}$ & $\begin{array}{c}-0.012 \\
301\end{array}$ & $\begin{array}{c}0.004 \\
232\end{array}$ & & & & $\begin{array}{c}0.037 \\
10\end{array}$ & $\begin{array}{c}0.068 \\
99\end{array}$ & $\begin{array}{c}0.091 \\
71\end{array}$ & & & \\
\hline $\begin{array}{r}\Delta \mathrm{HT}-\Delta \mathrm{LT}[2]- \\
{[1]}\end{array}$ & & $\begin{array}{c}0.096 \\
* *\end{array}$ & 0.004 & 0.011 & & & & 0.092 & 0.006 & 0.012 & & & \\
\hline
\end{tabular}




\section{Main bank- relationship and bank finance}

Table 8 presents our estimations of Equation (3) in which we examine the impact of the main bank-relationship of firms and their access to bank finance. We study two main bank characteristics: bank size and bank industry focus. Bank size is the total labor force of firms the bank serves as a main bank. We measure bank industry focus in two different ways. Bank expertise is the total number of firms in the same industry the bank serves as a main bank. Bank specialization measures the share of the bank's activities which are in the firm's industry. As we do not have information on the bank loan portfolios we use the total labor force of firms served by the bank in the industry, relative to the total labor force of all firms served by the bank.

For each of our three dependent variables Bank use, Bank share and Bank difficulties we present two specifications: Columns (1-3) present results that include Bank size and Bank expertise as main bank characteristics, while columns (4-6) present results that replace Bank expertise by Bank specialization as a measure of bank focus. We report OLS estimates for each specification, with standard errors clustered at the firm level reported in parentheses. Therefore the results for the dummy variables Bank use and Bank difficulties should again be interpreted within the context of a linear probability model.

All specifications suggest that firms that have their main relation with a larger bank use less bank finance and report more difficulties in getting credit. This is the case both for LowTech firms and High-Tech firms. The point estimate in columns (4-6) suggest that a one standard deviation increase in bank size $(202,370)$ from the mean $(113,719)$ would increase Bank use by 1.6 percentage points, Bank share by 0.8 percentage points, and reduce Bank difficulties by 1.1 percentage points. These effects are relatively small compared to the mean values of Bank use (65\%), Bank share (22\%) and Bank difficulties (38\%) among those firms that seek external finance. 
Results in columns 2 and 5 show that a larger expertise of the bank in the firm's industry measured either by absolute Bank expertise or relative Bank specialization - is associated with a larger share of bank finance. However, better knowledge of the industry does not seem to significantly reduce difficulties in getting credit (see columns 3, 6).

\section{Table 8. Bank relationship and bank finance}

All models include a full set of control variables, interaction terms between High tech and firm control variables as well as year dummies. All standard errors clustered by firms are reported in parentheses below the coefficients. Statistical significance at the $1 \%, 5 \%$, and $10 \%$ level is indicated by ***, **, and *, respectively.

\begin{tabular}{|c|c|c|c|c|c|c|}
\hline \multirow{2}{*}{ Firms } & \multicolumn{6}{|c|}{ Firms which require external finance } \\
\hline & Bank use & Bank share & $\begin{array}{r}\text { Bank } \\
\text { difficulties }\end{array}$ & Bank use & Bank share & $\begin{array}{r}\text { Bank } \\
\text { difficulties }\end{array}$ \\
\hline Industry & HT \& LT & $\mathrm{HT} \& \mathrm{LT}$ & $\mathrm{HT} \& \mathrm{LT}$ & HT \& LT & $H T \& L T$ & HT \& LT \\
\hline Model & $(1)$ & $(2)$ & (3) & $(4)$ & (5) & (6) \\
\hline \multirow[t]{2}{*}{ Bank size (log) } & $-0.021 *$ & $-0.019 * * *$ & $0.021 *$ & $-0.016 * * *$ & $-0.008 * *$ & $0.011^{*}$ \\
\hline & $(0.01)$ & $(0.01)$ & $(0.01)$ & $(0.01)$ & $(0.00)$ & $(0.01)$ \\
\hline \multirow[t]{2}{*}{ Bank expertise (log) } & 0.006 & $0.013^{*}$ & -0.011 & & & \\
\hline & $(0.01)$ & $(0.01)$ & $(0.01)$ & & & \\
\hline \multirow[t]{2}{*}{ Bank specialization } & & & & 0.001 & $0.001 * *$ & -0.001 \\
\hline & & & & $(0.00)$ & $(0.00)$ & $(0.00)$ \\
\hline \multirow[t]{2}{*}{ High-Tech } & 0.157 & -0.054 & -0.125 & $0.234^{*}$ & 0.068 & 0.016 \\
\hline & $(0.16)$ & $(0.09)$ & (0.16) & $(0.14)$ & $(0.09)$ & $(0.15)$ \\
\hline \multirow[t]{2}{*}{$H T^{*}$ Bank size (log) } & -0.011 & $0.018^{*}$ & $0.036 *$ & $-0.022 * *$ & -0.001 & 0.01 \\
\hline & $(0.02)$ & $(0.01)$ & $(0.02)$ & $(0.01)$ & $(0.01)$ & $(0.01)$ \\
\hline \multirow[t]{2}{*}{$H T^{*}$ Bank expertise (log) } & -0.015 & $-0.023 * *$ & -0.033 & & & \\
\hline & $(0.02)$ & $(0.01)$ & $(0.02)$ & & & \\
\hline \multirow[t]{2}{*}{ HT * Bank specialization } & & & & -0.004 & $-0.004 * * *$ & 0.003 \\
\hline & & & & $(0.00)$ & $(0.00)$ & $(0.00)$ \\
\hline \multirow[t]{2}{*}{ Constant } & $0.835^{* * *}$ & $0.441 * * *$ & 0.08 & $0.809 * * *$ & $0.345^{* * *}$ & 0.139 \\
\hline & $(0.08)$ & $(0.05)$ & $(0.09)$ & $(0.08)$ & $(0.05)$ & $(0.09)$ \\
\hline Observations & 4839 & 4022 & 4911 & 4839 & 4022 & 4911 \\
\hline Firm controls & yes & yes & yes & yes & yes & yes \\
\hline Firm controls * HT & yes & yes & yes & yes & yes & yes \\
\hline Year dummies & yes & yes & yes & yes & yes & yes \\
\hline Method & OLS & OLS & OLS & OLS & OLS & OLS \\
\hline log likelihood & -2900.97 & -419.64 & -3289.82 & -2900.51 & -416.05 & -3295.37 \\
\hline
\end{tabular}


Contrary to our expectations we do not find a robust stronger impact of Bank size, Bank expertise or Bank specialization on the use or access to bank credit for High-tech firms. The positive coefficient for the interaction term High-tech * Bank size in column (3) suggests that High-tech may face more difficulties in getting bank credit as opposed to Low-tech firms when they bank with a large bank. However, this result is not confirmed in column (6).

\section{$\underline{\text { Robustness tests }}$}

In the data section we mentioned that the ZEW/KfW panel oversamples start-ups that were stratified based on their KfW characteristics (see Fryges, Gottschalk, and Kohn (2010) for details). The KfW supports firms with promotional financial means like loans, equity and mezzanine capital, or grants. Because banks could behave differently when faced with firms that receive those subsidies, we check the robustness of our results by running all regressions in Table 5, 6, 7 and 8 excluding the KfW firms. All our results survive after dropping those observations with the exception of the one that pointed to High-Tech firms being more likely to have bank difficulties than Low-Tech firms (see Table 5). This effect disappears when we limit our sample to firms not supported by KfW, while High-Tech firms are still significantly different from Low-Tech firms in terms of use of bank finance. These findings suggest that among firms not supported by KfW although High-Tech firms use less bank finance than Low-Tech firms, this difference may be mostly demand-driven. 


\section{Conclusions}

This paper employs a unique dataset on German start-ups to study how banks screen start-ups in low-tech and high-tech sectors. We study whether the availability of external information - such as a credit rating granted by a credit bureau - impacts bank-credit availability and whether such a credit rating has differential impacts for High-Tech firms versus Low-Tech firms. Furthermore we investigate how the size of the firm's main bank influences a start-up's credit availability and whether a bank's focus and expertise has a differential role for low-tech and high-tech firms. These are important questions as start-ups are an important engine of economic growth and High-Tech firms may not have the necessary sources available to realize an economy’s potential.

We find that high-tech start-up firms are less likely to use bank finance and face more difficulties in raising bank finance than Low-Tech firms. This suggests that firms from industries that exhibit a greater research and development intensity employ less bank finance.

Our results also suggest that banks rely less on external rating information in their decision making for High-Tech firms. The availability of a credit rating hampers access to bank finance only when the rating is bad. Firms without rating or with a fair or good rating have similar access to bank finance suggesting that banks only employ negative signals from credit ratings in their decision making. We find an interesting difference between high-tech and low-tech firms as our results seem to indicate that a bad rating is less harmful in terms of bank finance for firms in the High-Tech sector than in the Low-Tech sector.

The size of a firm's main bank also determines whether start-ups face difficulties in obtaining bank finance. Our results suggest that firms that have their main relation with a larger bank use less bank finance and report more difficulties in getting credit. By contrast, a larger expertise of the bank in the firm's industry is not associated with fewer difficulties to 
get bank loans. We find no robust evidence that the impact of bank size is more pronounced for High-tech firms as opposed to Low-tech firms.

Our results have important policy implications. Policy makers might be concerned that financiers of innovative firms rely too much on credit ratings provided by credit bureaus. We find that this concern is unwarranted as banks seem to rely less on external ratings in their loan decision making for high-tech firms than for low-tech firms. Also, the trend towards more concentration in the banking sector may have detrimental impacts on credit availability for firms where loans are based upon soft information. We find that start-ups employing larger banks indeed face more difficulties in obtaining bank finance. However, this result applies for all types of start-ups - low-tech and high-tech - suggesting that a differential policy intervention for innovative firms is unwarranted. 


\section{References}

Bester, H. (1985): "Screening vs. Rationing in Credit Markets with Imperfect Information", American Economic Review, 31, 21-35.

Berger, A., M. Espinosa-Vega, W. Frame, and N. Miller (2005a): "Debt Maturity, Risk, and Asymmetric Information”, Journal of Finance, 60, 2895-2923.

Berger, A., W. Frame, and N. Miller (2005b): "Credit Scoring and the Availability, Price, and Risk of Small Business Credit”, Journal of Money, Credit \& Banking, 37, 191-222.

Boot, A.W.A. (2000): "Relationship Lending: What do we know?", Journal of Financial Intermediation, 9, 7-25.

Bolton, P. and D. Scharfstein (1990): "A Theory of Predation based on Agency Problems in Financial Contracting", American Economic Review, 80, 93-106.

Bozkaya, A. and B. van Pottelsberghe De La Potterie (2008): "Who Funds Technology-Based Small Firms? Evidence from Belgium", Economics of Innovation and New Technology, $17,97-112$.

Brown, M., T. Jappelli, and M. Pagano (2009): "Information Sharing and Credit: Firm-Level Evidence from Transition Countries", Journal of Financial Intermediation, 18, 151172.

Brown, M., and C. Zehnder (2007): "Credit Reporting, Relationship Banking, and Loan Repayment", Journal of Money, Credit, \& Banking, 39 (8), 1883-1918.

Cerqueiro, G., and M.F. Penas (2010): "Debtor Protection and Start-up Financing Sources: Evidence from the US", working paper.

Degryse, H., L. Laeven and S. Ongena (2009): "The Impact of Organizational Structure and Lending technology on Banking Competition", Review of Finance, 13, 225-259.

Djankov, S., C. McLiesh and A. Shleifer (2007): "Private Credit in 129 Countries", Journal of Financial Economics, 84, 299-329.

Doblas-Madrid, A., and R. Minetti. (2009): "Sharing Information in the Credit Market: Contract-Level Evidence from U.S. Firms", Working Paper Michigan State University.

Flannery, M.J., (1986): "Asymmetric Information and Risky Debt Maturity Choice", Journal of Finance, 41, 19-37.

Freixas, X. and J.J. Laffont (1990): "Optimal Banking Contracts", In Essays in Honour of Edmond Malinvaud, Vol. 2. Macoreconomics, ed. By P. Champsaur et al. Cambridge: MIT Press.

Fryges, H., S. Gottschalk, and K. Kohn (2010): "The KfW/ZEW Start-up Panel: Design and Research Potential", Schmollers Jahrbuch/Journal of Applied Social Sciences Studies, European Data Watch 130, 117-131.

Gompers, P. and J. Lerner (1996): "The use of covenants: An empirical analysis of venture partnership agreements", Journal of Law and Economics, 39, 463-98.

Hall, B.H. (2009): "The financing of innovative firms", European Investment Bank Papers, 14 (2), 8-28.

Harhoff, D. and T. Körting (1998): "Lending relationships in Germany - Empirical evidence from survey data", Journal of Banking and Finance, 22, 1317-1353. 
Jappelli, T., and M. Pagano (2002): "Information Sharing, Lending and Defaults: CrossCountry Evidence", Journal of Banking and Finance, 26, 2017-45.

Jappelli, T., and M. Pagano (2006): "Role and Effects of Credit Information Sharing", in The Economics of Consumer Credit, edited by G. Bertola, R. Disney and C. Grant. Cambridge: MIT Press, 347-371.

Kallberg, J., and G. Udell (2003): "The value of private business sector credit information sharing: The US case", Journal of Banking \& Finance, 27, 449-470.

Lerner, J. (1995): "Venture capitalists and the oversight of private firms", Journal of Finance, 50, 301-318.

Liberti, J. (2005): "Initiative, Incentives and Soft Information: How does Delegation Impact the Role of Bank Relationship Managers?" IFA Working Paper No.404.

Liberti, J. and A. Mian (2009): "Estimating the Effect of Hierarchies on Information Use", Review of Financial Studies 22, 4057-4090.

Padilla, A. J., and M. Pagano (1997): "Endogenous Communication among Lenders and Entrepreneurial Incentives", Review of Financial Studies, 10, 205-236.

Pagano, M., and T. Jappelli (1993): "Information Sharing in Credit Markets", Journal of Finance, 43, 1693-1718.

Robb, A.M., and D. T. Robinson (2012): "The Capital Structure Decision of New Firms", working paper, Kauffman Foundation.

Stein, J. C. (2002): "Information Production and Capital Allocation: Decentralized versus Hierarchical Firms" Journal of Finance 57, 1891-1921.

Stiglitz, J. E. and A. Weiss (1981): "Credit rationing in markets with imperfect information", American Economic Review, 71, 393-410. 


\section{Appendix}

\section{Table A-1. Explanatory variables}

This table presents definitions, sources and summary statistics for our explanatory variables, with the main explanatory variables presented in Panel A and control variables presented in Panel B. Data sources are either the KfW/ZEW Start-up Panel (SuP), Mannheim Enterprise Panel (MUP), Bank Panel (BP), or Statistical Office (SO). Bank size, Bank expertise and Bank specialization are based on firm-bank relationships, whereby nationwide banks are split roughly at the State level (bank-clearing level 2 according to the German Bundesbank).

\section{Panel B. Control variables}

\begin{tabular}{|c|c|c|c|c|c|c|c|}
\hline & Obs & Mean & Median & Min & Max & Definition & Source \\
\hline Firm age & 15000 & 2.42 & 2 & 1 & 5 & $1-5$ years & SuP \\
\hline $\begin{array}{l}\text { Management } \\
\text { team }\end{array}$ & 15000 & 0.29 & 0 & 0 & 1 & $\begin{array}{l}1 \text { if firm is managed by two or more; } 0 \\
\text { otherwise }\end{array}$ & SuP \\
\hline Employees & 15000 & 3.99 & 2 & 0 & 255 & Number of full-time equivalent employees & SuP \\
\hline $\begin{array}{l}\text { Limited } \\
\text { company }\end{array}$ & 15000 & 0.30 & 0 & 0 & 1 & 1 if firm is a limited liable company. & SuP \\
\hline Sales & 15000 & 330 & 80 & 0 & 160000 & Total sales in previous year in 1,000 EUR & SuP \\
\hline Private Equity & 15000 & 0.04 & 0 & 0 & 1 & $\begin{array}{l}1 \text { if external equity or mezzanine capital was } \\
\text { used (any time); } 0 \text { otherwise }\end{array}$ & SuP \\
\hline $\begin{array}{l}\text { Master } \\
\text { craftsman }\end{array}$ & 15000 & 0.24 & 0 & 0 & 1 & $\begin{array}{l}1 \text { if at least one manager holds a master } \\
\text { craftsman certificate; } 0 \text { otherwise }\end{array}$ & SuP \\
\hline $\begin{array}{l}\text { University } \\
\text { degree }\end{array}$ & 15000 & 0.41 & 0 & 0 & 1 & $\begin{array}{l}1 \text { if at least one team member holds a } \\
\text { university degree; } 0 \text { otherwise }\end{array}$ & SuP \\
\hline Experience & 15000 & 0.08 & 0 & 0 & 1 & $\begin{array}{l}1 \text { if the manager either had sold a previous } \\
\text { business, has another business or is a } \\
\text { restarter; } 0 \text { otherwise }\end{array}$ & SuP \\
\hline Real estate & 15000 & 0.08 & 0 & 0 & 1 & $\begin{array}{l}1 \text { if the firm or manager owns a private and } \\
\text { or business property; } 0 \text { otherwise }\end{array}$ & MUP \\
\hline Manufacturing & 15000 & 0.33 & 0 & 0 & 1 & $\begin{array}{l}1 \text { if firm is in a manufacturing industry; } 0 \\
\text { otherwise }\end{array}$ & SuP \\
\hline Exit rate & 15000 & 11.1 & 11.2 & 1.6 & 19.1 & $\begin{array}{l}\text { Share per industry (Nace } 3 \text { digit level) of } \\
\text { firms that failed within } 3 \text { years after start-up }\end{array}$ & MUP \\
\hline Unemployment & 15000 & 6.6 & 5.9 & 1.4 & 18.3 & $\begin{array}{l}\text { Rate of unemployment in the firms district } \\
\text { in the particular year }\end{array}$ & SO \\
\hline Year 2007 & 15000 & 0.35 & 0 & 0 & 1 & 1 if year of observation is $2007 ; 0$ otherwise & SuP \\
\hline Year 2008 & 15000 & 0.33 & 0 & 0 & 1 & 1 if year of observation is $2008 ; 0$ otherwise & SuP \\
\hline
\end{tabular}


Table A-2. Other sources of external finance

Panel A presents the summary statistics of the further financing sources. In panel B the left columns entitled "All firms" contain all observations available for the empirical analysis. The right columns entitled "Firms desired external finance" restrict observations $t$ those firms that either used external finance and / or stated financial difficulties seeking external finance. Panel B presents the summary statistics related to the firms' age. Panel C presents summary statistics related to industry or innovation classification to firms seeking external finance only. Firms industry classification is related to the product with the largest sales potential.

Panel A - Summary statistics

\begin{tabular}{|c|c|c|c|c|c|c|c|}
\hline & $\begin{array}{l}\text { No. of } \\
\text { firm- } \\
\text { years }\end{array}$ & mean & median & $\min$ & $\max$ & Definition & Source \\
\hline $\begin{array}{l}\text { Federal } \\
\text { employment } \\
\text { agency }\end{array}$ & 14,996 & 0.09 & 0 & 0 & 1 & $\begin{array}{l}1 \text { if either at least one team member } \\
\text { received a start-up grant by the } \\
\text { federal employment agency (the } \\
\text { grant covers the amount of } \\
\text { unemployment benefit and social } \\
\text { security costs); } 0 \text { otherwise }\end{array}$ & SuP \\
\hline $\begin{array}{l}\text { Federal } \\
\text { employment } \\
\text { agency share }^{1}\end{array}$ & 1,087 & 0.13 & 0.08 & 0 & 1 & $\begin{array}{l}\text { Volume of start-up grant finance to } \\
\text { total financing volume }\end{array}$ & SuP \\
\hline $\begin{array}{l}\text { Family and } \\
\text { friends }\end{array}$ & 14,998 & 0.06 & 0 & 0 & 1 & $\begin{array}{l}1 \text { if either loan from family members } \\
\text { or friends is used; } 0 \text { otherwise }\end{array}$ & SuP \\
\hline $\begin{array}{l}\text { Family and } \\
\text { friends share }{ }^{1}\end{array}$ & 746 & 0.17 & 0.10 & 0 & 1 & $\begin{array}{l}\text { Volume of loans by family members } \\
\text { and friends to total financing volume }\end{array}$ & SuP \\
\hline External equity & 14,999 & 0.03 & 0 & 0 & 1 & $\begin{array}{l}1 \text { if either Private Equity, Venture } \\
\text { Capital, capital by business angels } \\
\text { were used of shares were sold; } 0 \\
\text { otherwise }\end{array}$ & SuP \\
\hline $\begin{array}{l}\text { External equity } \\
\text { share }^{1}\end{array}$ & 289 & 0.31 & 0.20 & 0 & 1 & $\begin{array}{l}\text { Volume of external equity to total } \\
\text { financing volume }\end{array}$ & SuP \\
\hline $\begin{array}{l}\text { Mezzanine } \\
\text { capital }\end{array}$ & 14,999 & 0.01 & 0 & 0 & 1 & $\begin{array}{l}1 \text { if mezzanine capital is used; } 0 \\
\text { otherwise }\end{array}$ & SuP \\
\hline $\begin{array}{l}\text { Mezzanine } \\
\text { capital share }{ }^{1}\end{array}$ & 80 & 0.29 & 0.19 & 0 & 1 & $\begin{array}{l}\text { Volume of mezzanine capital to total } \\
\text { financing volume }\end{array}$ & SuP \\
\hline $\begin{array}{l}\text { External finance } \\
\text { desired }\end{array}$ & 15,000 & 0.40 & 0 & 0 & 1 & $\begin{array}{l}1 \text { if either the firm used or reported } \\
\text { difficulities with at least one of the } \\
\text { above mentioned sources of external } \\
\text { finance; } 0 \text { otherwise }\end{array}$ & SuP \\
\hline
\end{tabular}

${ }^{1}$ Shares are reported only for those firms that used the particular source of finance.

Panel B - Mean values by industry (only firms seeking external finance)

\begin{tabular}{lr|rr}
\hline \hline & All & Low-tech & High-Tech \\
\hline Federal employment agency & 0.22 & 0.25 & 0.17 \\
Family and friends & 0.16 & 0.17 & 0.13 \\
External equity & 0.06 & 0.04 & 0.11 \\
Mezzanine capital & 0.02 & 0.01 & 0.03 \\
\hline No. of firm-years & 6,019 & 4,015 & 2,004 \\
\hline \hline
\end{tabular}




\section{Table A-3. Credit rating and volume of bank finance: Panel analysis}

This table presents the effect of rating availability on the volume of bank finance (in thousand EURO). In this analysis only firms are considered for which in the previous rating no rating was available. The figures present the mean. Asterix indicate whether the reported mean values are significantly different for firms which received Bad vs. Fair, Fair vs. Good or Bad vs. Good ratings at the * 0.1, ${ }^{* *} 0.5$, or *** 0.01 level of significance.

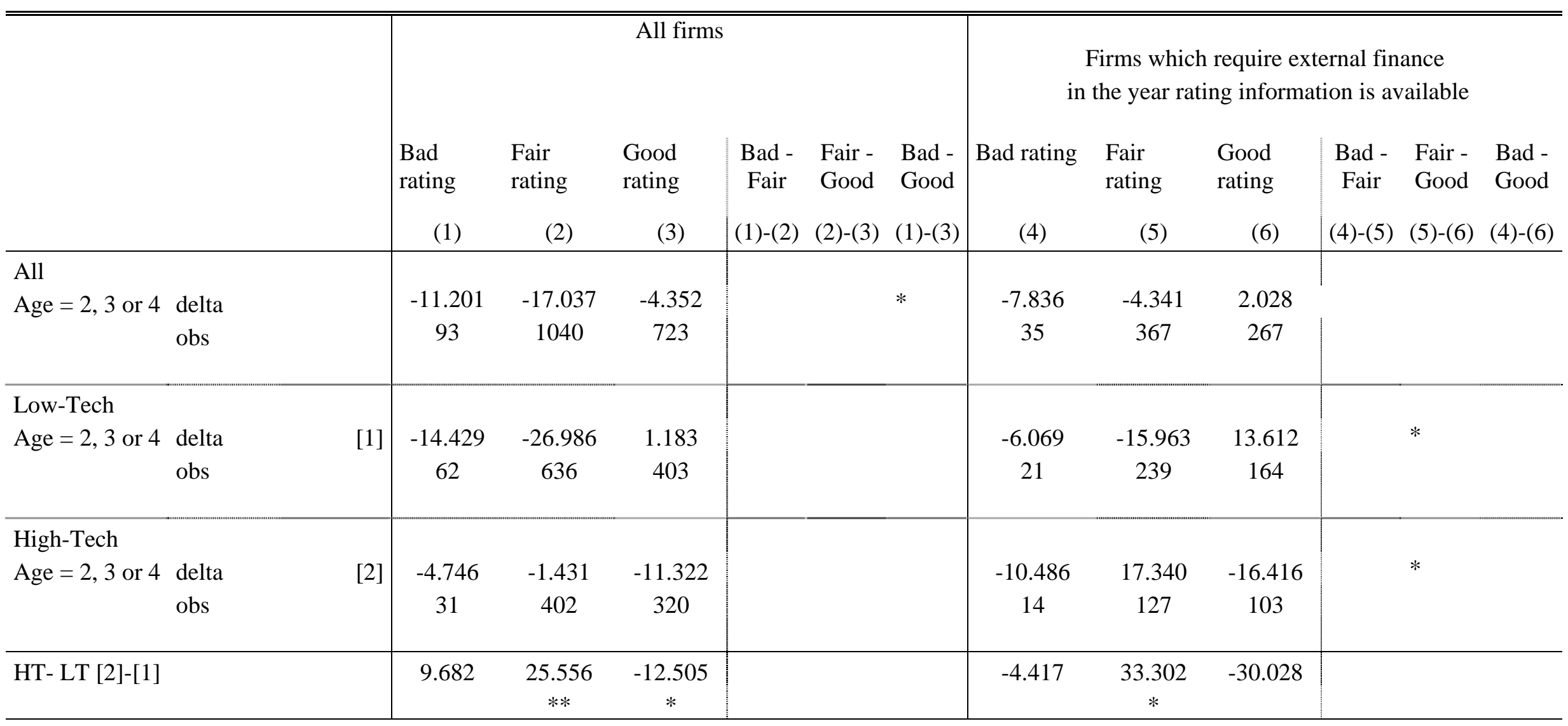




\section{Table A-4. Credit rating and loans by family and friends: Panel analysis}

This table presents the effect of rating availability on the share of loans provided by family members or friends to total financing volume. In this analysis only firms are considered for which in the previous rating no rating was available. The figures present the mean. Asterix indicate whether the reported mean values are significantly different for firms which received Bad vs. Fair, Fair vs. Good or Bad vs. Good ratings at the * 0.1, ** 0.5, or *** 0.01 level of significance.

\begin{tabular}{|c|c|c|c|c|c|c|c|c|c|c|c|c|}
\hline & & \multicolumn{6}{|c|}{ All firms } & \multicolumn{5}{|c|}{$\begin{array}{l}\text { Firms which require external finance } \\
\text { in the year rating information is available }\end{array}$} \\
\hline & & $\begin{array}{l}\begin{array}{l}\text { Bad } \\
\text { rating }\end{array} \\
(1)\end{array}$ & $\begin{array}{l}\text { Fair } \\
\text { rating } \\
(2)\end{array}$ & $\begin{array}{l}\text { Good } \\
\text { rating } \\
(3)\end{array}$ & $\begin{array}{l}\text { Bad - } \\
\text { Fair } \\
(1)-(2)\end{array}$ & $\begin{array}{l}\text { Fair - } \\
\text { Good } \\
(2)-(3)\end{array}$ & $\begin{array}{l}\text { Bad - } \\
\text { Good } \\
(1)-(3)\end{array}$ & $\begin{array}{c}\text { Bad rating } \\
\text { (4) }\end{array}$ & $\begin{array}{l}\text { Fair } \\
\text { rating } \\
(5)\end{array}$ & $\begin{array}{r}\text { Good } \\
\text { rating } \\
(6) \\
\end{array}$ & \begin{tabular}{|cc} 
Bad - & Fair - \\
Fair & Good \\
$(4)-(5)$ & $(5)-(6)$
\end{tabular} & $\begin{array}{l}\text { Bad - } \\
\text { Good } \\
(4)-(6)\end{array}$ \\
\hline $\begin{array}{l}\text { All } \\
\text { Age }=2,3 \text { or } 4 \text { delta } \\
\text { obs }\end{array}$ & & $\begin{array}{c}-0.009 \\
66\end{array}$ & $\begin{array}{c}0.002 \\
750\end{array}$ & $\begin{array}{l}0.003 \\
508\end{array}$ & & & $*$ & $\begin{array}{c}-0.005 \\
27\end{array}$ & $\begin{array}{c}0.016 \\
277\end{array}$ & $\begin{array}{c}0.013 \\
191\end{array}$ & & \\
\hline $\begin{array}{l}\text { Low-Tech } \\
\begin{aligned} \text { Age }=2,3 \text { or } 4 \text { delta } \\
\text { obs }\end{aligned}\end{array}$ & {$[1]$} & $\begin{array}{c}-0.009 \\
44\end{array}$ & $\begin{array}{c}0.000 \\
448\end{array}$ & $\begin{array}{c}0.005 \\
277\end{array}$ & & & & $\begin{array}{c}0.005 \\
17\end{array}$ & $\begin{array}{c}0.012 \\
178\end{array}$ & $\begin{array}{c}0.021 \\
120\end{array}$ & & \\
\hline $\begin{array}{l}\text { High-Tech } \\
\text { Age }=2,3 \text { or } 4 \text { delta } \\
\text { obs }\end{array}$ & {$[2]$} & $\begin{array}{c}-0.010 \\
22\end{array}$ & $\begin{array}{c}0.006 \\
300\end{array}$ & $\begin{array}{c}-0.001 \\
231\end{array}$ & & & & $\begin{array}{c}-0.022 \\
10\end{array}$ & $\begin{array}{c}0.024 \\
98\end{array}$ & $\begin{array}{c}0.000 \\
71\end{array}$ & $* *$ & \\
\hline HT-LT [2]-[1] & & -0.001 & 0.006 & -0.006 & & & & -0.027 & 0.011 & $\begin{array}{l}-0.021 \\
*\end{array}$ & & \\
\hline
\end{tabular}

